Last revision: 23 December 2020

Publication: Competition and Regulation in Network Industries, 2021, Vol. 22, No 2, pp. 71-86

\title{
Entitlement problems in digital markets and how antitrust shapes the appropriation of network externalities
}

Linus J. Hoffmann

\begin{abstract}
The engine of value creation in the digital economy is network externalities, i.e. the phenomenon by which the value to a new user from adopting a good or service increases in the number of users who already adopted it. But network externalities are not manna from heaven. They are "sponsored" by firms who make demand expanding investments. In areas with imperfect property institutions like the digital economy, a key business decision for profit maximizing firms consists in devising value capture strategies to appropriate their investments.

We identify three recurrent types of appropriation disputes in digital markets: Access to software platforms, limitations to the exploitation of raw data and claims over digital content. At the heart of each dispute lies the controversial exercise of an entitlement over a digital asset that is embedded in a context of or exhibits itself network externalities. The appropriation of this asset and its integration into the firm's ecosystem could make the firm benefit from network efficiencies. Controlling the digital asset in question becomes a proxy.

Appropriation strategies by proxy can have pro- and anti-competitive effects. This is why each dispute can not only be understood as a problem of appropriability, but also as a problem of potential harm to competition. And indeed, competition enforcers have brought forward various cases with underlying appropriation disputes. This paper tracks the influence of three of them on the appropriability of assets in the digital economy, and on digital firms' strategies to capture the value of network externalities.
\end{abstract}

\section{Introduction: Digital markets disputes as problems of entitlement}

Network externalities are the driver of value creation in the digital economy. In general, "a good exhibits network effects if the value to a new user from adopting the good is increasing in the number of users who have already adopted it. This generates a positive feedback loop: the more users who adopt the good, the more valuable it becomes to potential adopters. This positive feedback loop also works in reverse: if adoption fails to reach a critical mass of users, the good or service may fall into a "death spiral" and ultimately disappear" (Varian, 2017, p. 1). With direct network externalities, we expect a good or service to become more attractive for a new user when more users like him have already adopted it, which in turn allows the firm to extract more value from their interactions. Indirect network externalities arise between different groups of users, like for example private users and advertisers on a social network. The attractiveness of the good or service is expected to increase when the different user groups grow, and when their interaction is well orchestrated by the digital firm.

Network externalities are not a good that can be owned by the means of private property. Apart from a state-granted monopoly, there are no direct legal means that would allow a single firm to exploit the entire network externalities in a given product market. But network externalities are neither a public good that can be exploited by everyone. Therefore, digital firms compete to capture them. In the absence of the classic legal tools of appropriation, one way for firms to exploit network externalities is to carefully design and equilibrate single- and multi-sided markets with complex pricing structures. Firms 
can have great struggles in doing so. ${ }^{1}$ Another way to capture the value of network externalities is to appropriate digital assets that stand as their proxies. This is the object of our study.

In a first step, this paper sets out three types of disputes over digital assets: Access to software platforms, limits to the exploitation of raw data and data structures and claims over digital content. Many conflicts in digital markets can be analysed through the prism of one of these schemes. At the heart of each lies the controversial exercise of an entitlement over a digital asset. Similar to Coase's cattle and crops (and actually any conflict that law deals with), each dispute can be reduced to a simple question: to which party should the legal entitlement in dispute be allocated? This happens in a context in which legal institutions have not arisen to manage the entitlement conflict. And existing institutions of entitlement allocation (often classic private property rights and regulatory action with limited scope) on which agency and courts might be tempted to fall back do not always provide socially optimal solutions. Indeed, it's no news that during a period of technological advancement, new markets require the emergence of new property rights or at least the attuning of existent ones to the new reality (Demsetz, 1967, p. 350). All three disputes might thus require a (re-)allocation.

The disputes have a common characteristic. The appropriation of each asset and their integration into a digital firm's ecosystem can be considered to be a gateway for the firm to capture the value of untapped network efficiencies. Digital firms do not strive for control over the digital asset for its own sake, but because it is a proxy for consolidating network efficiencies.

The exploitation of untapped network efficiencies can have pro- and anti-competitive effects according to the market context in which they are leveraged. This is why each dispute can not only be understood as a problem of appropriability, but also as a problem of potential harm to competition. And indeed, each of our disputes has been dealt with by competition agencies.

Competition law plays a role in the normative resolution of all three entitlement problems. The goals and reasoning of property law are as relevant for each dispute as competition law's proper goals and reasoning. And in effect, perhaps more than purpose, competition law can be conceived as a system of entitlement allocation. Therefore, the aim of this paper is to show how competition law affects the exercise of entitlements over digital assets in the pursuit of its own goals. How does competition law enforcement affect digital firms' strategies to capture the value of network externalities?

This brings answers to the question if the modus operandi of competition law is only ex post, a mere market correcting device, or also ex ante. If the enforcement of competition law shapes property entitlements in the context of strong direct or indirect network externalities, then it could be said to structure the functioning of markets ex ante. If that should be true, the responsibility of competition decision makers would change. They would become the avant-garde for determining new market ordering rules in times of technological change. This is important at more than one level. One, this is a great responsibility for competition decision makers, that needs to be made explicit, so appropriate consideration is given to the welfare trade-offs involved in the setting of entitlement regimes. In fact, much of these trade-offs are generally devolved to lawmakers. Two, competition decision makers like to think of themselves as technology neutral (Petit \& Van Cleynenbreugel, 2020, p. 29). Yet, the resolution of entitlement problems is not technology neutral, for it affects the distribution of value that arises from new technology.

\section{First entitlement problem: Access to software platforms}

Some pieces of software, like operating systems, app stores or internet search engines, have some characteristics in common with physical network infrastructure.

Similar to physical networks, firms on dependent markets rely on access to the software platform to deliver their own products. Vertical integration into the dependent markets by a firm that controls such a software platform can give it a competitive advantage over the non-integrated firms. However, unlike

\footnotetext{
${ }^{1}$ This is known as the chicken-and-egg problem of multi-sided markets (Hagiu, 2014, p. 5).
} 
physical infrastructure networks, a software platform is an exclusively intangible good. That is to say, the software platform is hard to replicate for competitors not so much because of supply side costs or technological advantages, but because of demand side properties (the uncertainty of the emergence of network externalities, especially in multi-sided markets), tipping and winner takes all effects.

Competition law enforcement in the digital economy can help to localize situations where problematic forms of appropriation of digital platforms take place. In fact, there seems to be a genuine run towards their capture by digital firms. Our example is the Google Android case from 2018.

The EC Google Android case is about three different types of abusive conduct. We focus on the set of questions around Google's anti-fragmentation agreements and the modified versions of the Android smartphone operating system (Android OS), the so-called Android forks (Commission Decision of 18.7.2018 relating to a proceeding under Article 102 of the Treaty on the Functioning of the European Union (the Treaty) and Article 54 of the EEA Agreement (AT.40099 - Google Android), 2018). For the context, the developer of Android OS was acquired by Google in 2005. Google handles the Android OS an open-source project. That is to say, beneath creating its own versions of it, Google gives third party developers free access to the source code and allows them to create their own versions. However, Google maintained a decisive influence on the development of the Android ecosystem. Via the so-called anti-fragmentation agreements, Google obliged all the equipment manufacturers who wanted to preinstall on their mobile device certain proprietary apps of Google, namely the Play Store and Google Search, to commit to not develop or sell any devices running on Android forks. This made Google's own version of the Android OS the only viable OS for hardware manufacturers, because smartphone users strongly value access to Google's proprietary apps, namely the Play Store, which gives access to third party apps. This is the critical point in the EC case.

The EC, after having set out that Google has a dominant position in the markets of general internet search services, licensable smart mobile operating systems and app stores for the Android mobile OS, decided that Google abused its dominant position by effectively hindering the development of Android forks that could become a competitive threat to its own versions. By preventing the installation of its proprietary apps on Android forks, Google impeded alternative Android OSs to prosper, that could have promoted alternatives to the Play Store and to the Google Search engine. That way, the prevention of Android forks strengthened its position in all the three markets in which the EC found Google to be in a dominant position. As the main part of Google's income was generated by adds in its search engine, the EC estimated that the final goal of the different abuses was to increase traffic for the Google search engine. In other words: By excluding the commercial viability of Android forks, Google tried to increase user engagement with one of their products that benefits from strong indirect network effects. The viability of the Google search service depends on a high and stable engagement by users and advertisers.

The EC decided to fine Google by a record $€ 4.3$ billion for the three different anticompetitive practices combined (here we only focused on one of them). As to the anti-fragmentation agreements, the EC ordered Google to cease to impede hardware manufacturers to sell devices based on Android forks. To sum up the competition reasoning, the EC fined Google for having captured the Android OS as a proxy to leverage the indirect network efficiencies for their search service.

The underlying entitlement conflict can now be identified. The parties in the conflict are Google on the one side, main developer of the Android ecosystem, and hardware manufacturers on the other side, who are in need of installing an OS on their devices in order to sell functional smartphones. Android being a widespread product, hardware manufacturers could either install the Google version of Android and accept not to develop forks, or create their own fork, and accept not to get the Play Store and other Google proprietary apps. The entitlement in dispute concerns the very existence of forks and could be distributed in two ways. One form of conflict resolution could be to give Google the entitlement to exclude others from modifying and selling smartphones with a modified version of the OS that it has acquired in 2005. The other form of resolution could be to grant the hardware manufacturers the entitlement to modify and sell smartphones with their forks without being penalised for it.

If that situation is interpreted from the perspective of appropriation, it becomes clear that the respective entitlements refer to a common object, Android OS. In the language of property, the respective 
entitlements concern the capacity of a party to exclude the other from interacting with the common object. That means, independently of how the entitlement is distributed, the solution of the conflict will necessarily give to one party the "power to control, to varying degrees, [other people's] behavior in connection with the thing" (Perzanowski \& Schultz, 2016, Chapter 2, "Property and the Exhaustion Principle", para. 22) which is a standard definition of ownership. That is why we can interpret the situation as a problem of appropriation. Under the hood of the competition case, the situation reveals itself as a dispute over access and modification rights of Android OS.

What is the thing that firms try to appropriate? As a piece of software, the Android source code has the properties of an intangible good. Being an open source project, it has been expressly designed by Google to be non-excludable once released in the world. That is why Google needed to use contractual means (the anti-fragmentation agreements) to prevent the rise of competitive forks and make the Android source code a more excludable good.

The Android source code is also a rivalrous good. On a first look, when considering the source code only by itself, one could argue that code does not become scarce or diminish in value when it is used or modified. However, when we take into account the commercial context of Google, the value of the source code does indeed diminish for Google if other firms create their forks. This happens indirectly. For Google, the danger of forks is that the manufacturers can decide to preinstall different search engines than the Google one. This would deviate traffic to other internet search engines, which would diminish Google's revenues from its own search engine. Even if Google promotes Android as an opensource project, every fork that uses a different search engine than the Google one means a loss in revenue. In other words, even if the interdependencies between search engine market and mobile OS market make things more complicated, in the end, Google does not want anyone to take a bite of its apple, because that diminishes its value. In the context of digital markets, the Android source code is a rivalrous good.

It becomes clear that the exercise of property rights has been shaped after the intervention of competition law, although not explicitly. The outcome of the EC case is that hardware manufacturers are granted access and modification rights and the right to sell modified versions of an OS that was and is still formally owned by Google. The Google Android decision shifted Google's ownership position of Android OS a bit towards the more precarious end.

Android OS is an example of a software platform that was managed in order to benefit from untapped network effects of two related software platforms. Eliminating alternative versions of Android OS permitted to maintain or increase user engagement with the Google search engine and the Google Play Store.

Other items of such software platforms could be all types of app stores and general internet search engines, but also online ad space, ${ }^{2}$ specialised comparison websites ${ }^{3}$ or the leading search engine for GIFs. ${ }^{4}$ They all have in common that they are gateways to important network externalities. Related digital assets can be captured and used in order to increase engagement with them. When a software

\footnotetext{
2 The rationale of this section can be applied to the EC Google Search (Adsense) case. Here, Google tried to appropriate the advertising space on third party websites. It did so via exclusivity clauses, prohibiting websites from placing adverts from Googles competitors; via so called "Premium Placement" clauses, obliging websites to place Google ads on the most advantageous positions; and via requiring websites to seek written consent if they changed the presentation of rival adverts on their site (European Commission, 2019a).

3 The Google Shopping case concerns the question of self-preferencing. Should third party websites have the entitlement not to be demoted in Google's search engine results? (Commission Decision of 27.6.2017 relating to proceedings under Article 102 of the Treaty on the Functioning of the European Union and Article 54 of the Agreement on the European Economic Area (AT.39740_Google Search (Shopping)), 2017).

${ }^{4}$ In May 2020, Facebook acquired Giphy for a reported value of USD 400 million. Giphy's GIF search engine is integrated in services that are not part of Facebook, like Twitter, Snapchat, Reddit, Slack and Tiktok. Facebook and Giphy assured that Giphy's trading partners will have have continous access to the search engine (Matsakis, 2020; Shah, 2020).
} 
platform becomes a crucial input for trading partners, then the owner's behaviour becomes a potential target for competition investigations.

\section{Second entitlement problem: Limits to the exploitation of raw data and data structures}

The second entitlement dispute is about the exploitation of raw data and data structures in the context of digital networks. A certain amount of data collection and appropriation is inherent to the business model of many digital firms. For example, the data that Facebook collects from the users ultimately permit the firm to provide their social network service for free. At the same time, much of firms' output that emerges from data collection can be also conceived as a by-product of the data subject's own behaviour. Should collected data belong in the first place to the data subject?

Similar to the first entitlement problem, the appropriation and exploitation of raw data and data structures can stand as a proxy for the capture of supplementary network externalities. The issue is to what extent firms should be able to do so in the particular context of personal user data, especially when markets have tipped. ${ }^{5}$ Our example is the ongoing tale of the 2014 Facebook/Whatsapp merger, and in particular the question whether automatic profile matching between Facebook and Whatsapp users should be allowed.

For the context, Facebook collects data of its social network users and creates user preference profiles that enable targeted advertising. It generates revenue from selling targeted add space on its social network website to advertisers. Network externalities arise because of the coexistence of advertisers on the one side, who need a targeted public for their adds, and social network users on the other, who benefit from free communications tools. The social network is free for users because it is subsidized by the advertisers' placement fees.

The EC authorised Facebook to acquire Whatsapp for USD 19 billion in 2014. In its decision, the EC set out that both firms were not close competitors. The EC investigated three markets: Consumer communications services, social networking services, and online advertising services. Our focus is on online advertising services. The decision set out that only Facebook was active in the online advertising sector in 2014, but not Whatsapp. At that moment, 70 - $90 \%$ of Whatsapp's active users were also using Facebook (Case M.7217 - Facebook/ WhatsApp. Commission decision pursuant to Article 6(1)(b) of Council Regulation No 139/2004, 2014, paras. 165-166).

The EC assessed possible harm to competition in the online advertising sector by analysing two potential outcomes of the merger. The first outcome, Facebook introducing direct advertising on the Whatsapp service, was considered harmless for competition, as enough competitors were deemed to existed. The second outcome, Facebook collecting personal data from Whatsapp and using it for more precise targeted advertising on Facebook, was also considered to be harmless. One of the reasons for that was that Facebook submitted to the EC that matching the user profiles of Whatsapp and Facebook would be technically impossible (Case M.7217 - Facebook/WhatsApp. Commission decision pursuant to Article 6(1)(b) of Council Regulation No 139/2004, 2014, paras. 164-190). This turned out to be a false declaration. After having announced in 2016 to match the profiles and integrate both services, Facebook was fined by the EC in 2017 for providing incorrect or misleading information during the merger procedure. However, it did not revoke the merger approval (Case No. M.8228 - Facebook / Whatsapp. Commission Decision of 17.5.2017 imposing fines under Article 14(1) of Council Regulation (EC) No. 139/2004 for the supply by an undertaking of incorrect or misleading information, 2017).

In 2019, the German Bundeskartellamt has taken up the same conflict again, but on slightly different grounds. Its argumentation was based on a combination between competition law elements and data protection rights of users, arguing that users had no choice other than to accept profile matching when

\footnotetext{
${ }^{5}$ Market tipping means that at some point in the growing adoption of a service by users, one can expect a high and relatively stable level of participation. However, that does not oppose that markets can un-tip (Petit, 2020, pp. 81-82).
} 
using the services, which led to a lower standard of privacy protection. Consequently, the Bundeskartellamt prohibited automatic profile matching. ${ }^{6}$ Later, the Düsseldorf Higher Regional Court blamed the authority for the methodological mixture between competition and privacy aspects and cancelled the authority's interim measures (Beschluss VI-Kart 1/19 (V), Facebook v Bundeskartellamt, 2019). Finally, the Bundesgerichtshof upheld the initial decision on provisional measures, but on slightly different grounds (Bundesgerichtshof. Beschluss des Kartellsenats vom 23.6.2020—KVR 69/19, 2020). The decision on the merits of the case is pending. Finally, the recent EC's proposal for a Digital Services Act contains a provision that would enshrine the essence of the Bundeskartellamt's decision in a regulatory text (Proposal for a Digital Markets Act, art 5(a), 2020).

So, what is the entitlement conflict about? It is safe to say that if the Facebook and Whatsapp services are allowed to integrate and to match profiles, additional positive network externalities will arise. Facebook would have an even more accurate preference profiles of the users, which would make targeted adds more precise and valuable. ${ }^{7}$ Users on the other hand would lose control over their data. The underlying entitlement dispute revolves around the exploitation of the supplementary network externalities that would arise from matching the two user bases. The conflict could be solved in several ways. One, Facebook could simply receive the entitlement to exploit the user data by matching profiles. Two, the users could receive the entitlement not to be exploited by matching. Three, users could obtain the choice to accept matching or not. This could be done via opt-ins or opt-outs, but it would basically shift the entitlement to the users. ${ }^{8}$

The competition case exposes a dispute over the right to exploit user data in order to benefit from supplementary network externalities. What Facebook wanted to appropriate in 2014 was probably not Whatsapp as a business itself, nor its mere userbase, but the very possibility to capture supplementary network externalities by matching the new with the existing user base. Indeed, in business literature, some mergers are envisioned in order to acquire an "active and dynamic community".?

From a property perspective, two characteristics can be attached to user data. First, they are to a certain degree an excludable. Once digital firms captured a user base, there are ways to exclude competitors from having access to it. Firms can implement strategies to impede multi-homing and foster user lockin, hindering users to switch to a competitor's service, and therefore keeping the benefits of network externalities on their own platform. With multi-homing obligations, competition deciders could render user data and their network externalities more non-excludable, making switching between services easier, and allowing for less capture. ${ }^{10}$

Second, that type of raw user data is also a rivalrous good for a firm. In other words, if users do not only give access to their data on Facebook, but also on Tiktok and on other networks, then the less exclusive the raw data collected by Facebook will be. The more users practice multi-homing, the more diminishes the value that a single firm can extract from its user data.

In our example, the appropriability of network externalities will be shaped according to the outcome of competition law intervention. Should the Bundeskartellamt prevail with its decision to prevent

\footnotetext{
${ }^{6}$ The authority declared that with this prohibition, "we are carrying out what can be seen as an internal divestiture of Facebook's data". This can be considered as an attempt to undo the negative effects of the merger, although realized only with behavioural remedies (Bundeskartellamt, 2019; Fallbericht vom 15 Februar 2019, B6-22-16. Facebook; Konditionenmissbrauch gemäß 19 Abs. 1 GWB wegen unangemessener Datenverarbeitung, 2019).

${ }^{7}$ For example, Facebook profiles could automatically be enriched by the personal phone number of the user, which is necessary for logging into Whatsapp. Technically, Facebook advertisers could then send ads to Whatsapp accounts.

${ }^{8}$ On a side note, even the decision between opt-in and opt-out is not neutral in terms as to the final entitlement distribution. Each option contains path dependencies. If opt-out is chosen, some users may not find the option to click on or may be unwilling to spend time to search it. If opt-in is chosen, Facebook could be tempted to propose the option aggressively in order to make people opt-in.

${ }^{9}$ Here, the Facebook/Whatsapp merger can be classified as a "strategic buy" (GIL, 2018, P. 355).

10 This is explained more in detail in the Crémer report (Crémer et al., 2019, p. 57).
} 
automatic profile matching, then Facebook will not be able anymore to capture the resulting network externalities. When it comes to the users, they have an interest in the prohibition of profile matching. For users, the dispute arises primarily from a privacy concern, i.e. a concern about the control of personal data. This touches on the fundamental debate if personal data should only be protected by fundamental rights, such as privacy rights, or if it should also be protected by property rights. Indeed, some argue that personal data should become a tradable good owned by the data subject (Zech, 2015). This, however, has brought up concerns about competitive harm, as it could foster the dominant position of data collecting firms in tipped markets (Petit, 2020, p. 203).

The dispute over limitations to the appropriability of raw data and data structures in the context of untapped network effects can be found in other situations, like for example the purchase of Instagram by Facebook. Microsoft's serious considerations to take over the communications tool Slack for USD 8 billion in 2016 can also be interpreted as a move to appropriate network externalities that could have arisen in combination with its Skype for Business service (Russel \& Lundgren, 2016).

A slightly different example of the second entitlement problem would be Amazon's alleged use of thirdparty sales data for creating its own products. Amazon is a vertically integrated firm. On its marketplace, Amazon sells products of its own brands beneath those that are sold by third parties. But contrary to the third parties, Amazon has access to the aggregate sales data of all the sellers on the platform. It has been alleged that Amazon employees use the sales data in order to design their own products and adapt their pricing strategies (Mattioli, 2020). The EC's investigation on Amazon concerning those facts could lead to a clarification of the appropriability of sales data of online marketplaces (European Commission, 2019b). The EC's proposal for a Digital Markets Act opts against their appropriability by the platform (Proposal for a Digital Markets Act, art. 6 (a), 2020).

\section{Third entitlement problem: Claims over digital content}

The third entitlement problem concerns claims over digital content that is exchanged on networks. Contrary to raw data, content is not only a by-product of human behaviour, but a product of human work. On multi-sided platforms, the exploitation of one side's content by a platform can nurture a high and stable participation on the other side. Here, appropriating content is yet another proxy for capturing network externalities. However, as it can take significant resources to create content, it may be reasonable to limit the appropriation of it by platforms.

Our example is a decision from the French Autorite de la concurrence (the Autorité) concerning the dispute between a group of press publishers and Google (Décision n ${ }^{\circ} 20-M C-01$ du 9 avril 2020, 2020). The case concerns the introduction of the so-called "neighbouring rights" of press publishers on snippets of their work that are displayed on different Google websites.

For the context, Google and other search engines display snippets of online press articles. A snippet is a preview of the article that contains a hyperlink to the publisher's website. For instance, the Google News service currently accessible from Italy displays the title of the article, the date, a few first sentences and a thumbnail of the photo that accompanies the article.

The EU Directive 2019/790 on copyright and related rights in the Digital Single Market created sui generis property rights for press publishers (Directive (EU) 2019/790, 2019). Publishers of copyrightprotected press publications are granted exclusive reproduction rights and rights to make the publications accessible to the public (art.15). These are the "neighbouring rights" and have a duration of 2 years. As if this was not clear enough, the directive insists on the fact that "online content-sharing service providers" (read: Google) must secure an authorisation of the right holders in order to make the press publications available to the public (art.17). There is no further indication on the negotiation process or a fair compensation. The legislator seemed to believe that it was sufficient to create a property right and let free bargaining between press publishers and "online-sharing service providers" play out. This did not go well for the press publishers.

Search engines (mainly Google) represent most of the traffic that is redirected towards the press publisher's webpages. That gives Google a strong bargaining position when it comes to obtaining the 
publishers' authorization to make the press publications available to the public. Google decided to no longer display snippets of the news content unless the press publishers granted Google the authorisation to do so free of charge. Most of the press publishers, depending on the traffic generated by Google towards their websites, have consequently granted Google the permission to display their content without remuneration. Also, with the new licences, the displayed snippets became richer in content than before (Autorité de la concurrence, 2020b).

The case was brought to the Autorité by a group of French press publishers. Besides their complaints on the merits of the case, they requested interim measures to enjoin Google to renegotiate in good faith the compensation for the licence to display the snippets and make them available to the public. In the decision on interim measures, the Autorité stated that Google is susceptible to have a dominant position on the general internet search services, given that it handles $90 \%$ of general search requests in France. By denying negotiations on the compensation for the licences, Google could have abused its dominant position. Furthermore, Google could also have committed an abuse of economic dependence (a particular feature of French commercial law). Interestingly, the Autorité interprets the goal of the directive and the transposed French law: "the Autorite notes that, in the state of the investigation, [Google's conduct] seems difficult to reconcile with the purpose and scope of the law, which aimed to redefine the sharing of value in favour of press publishers vis-à-vis platforms" (Autorité de la concurrence, 2020b). The Autorité, insisting on the financial difficulties of the press publishing sector, decided to enjoin Google to renegotiate in good faith the compensation for the license with the press publishers. The case on the merits is pending.

The entitlement dispute between Google and the press publishers is easy to identify. The central entitlement is the compensation for displaying. That is to say, the case is not about the existence of the so-called neighbouring rights; these are positive property rights that the legislator has already created. Rather, the case turns around the remuneration for the licensing of this right. The entitlement could be distributed in the favour of Google, by not imposing a duty to compensate the licensing; or in favour of the press publishers, by creating a duty to compensate. In a certain way, this entitlement dispute is about the very effectiveness of an already existing positive property right. If the final decision of the Autorite is in favour of the press publishers, and this seems likely, then it creates a positive market value for neighbouring rights.

When it comes to excludability and rivalry, we note similar characteristics to the other digital goods. Both firms try to appropriate the benefits of the published snippets. In order to attract readers over a search engine, publishers must disclose a minimum of information about their articles. The benefits arising from snippets could be to a certain degree excludable, for example if Google decided to purchase only exclusive licences for displaying snippets. It is however unsure if the Autorité would accept that. Snippets are also rivalrous in the commercial context; if it would be known that most readers accede to press articles via non-Google services, then the value of acquiring the right to display the snippets would decrease for Google.

A few words on the distributive aspect of this conflict. Both firms have an interest in publishing the snippets, but the press publishers' interest is much more urgent. And indeed, one could conceive the situation from a different angle. One could also hold the newspapers liable to pay Google for having their content displayed and contributing massively to the traffic on their sites. However, the neighbouring rights have been granted to press publishers because of their difficult financial situation, and incidentally because of their role for democracy (Directive (EU) 2019/790, 2019, recital 54; For the U.S. perspective, see Zingales et al., 2019, pp. 10-11). In the decision on interim measures, the Autorité follows the distributive reasoning of the legislator.

Another example for the third entitlement problem could be users granting a number of rights to Instagram when uploading content to the service. Although Instagram insists in their Terms of Use that it does not claim ownership over the content, users are required to give up substantial property rights 
on the content they upload. ${ }^{11}$ Instagram holds even the right to sub-license content. It is however doubtful to what extent it would do this on a massive scale, as users would feel tricked if their content would be resold by Instagram (Naidoo, 2017). That could lead to less content upload and lower user participation, endangering the viability of the network. This is another illustration that positive exclusive rights can have no effect at all in the presence of bargaining power (users turning away from the platform).

Finally, in order to participate in a platform, users must grant to digital firms some entitlements over the content that circulates when they interact with others in the service. A certain degree of weakening of their ownership positions regarding that content is part of the business model of platforms. However, the issue arises with the question to what extent digital firms should be able to appropriate content in order to increase overall participation, especially when distributional or non-economic factors come into play.

\section{Finding: Competition law does shape the appropriation of network externalities in digital markets}

Although competition law has not been conceived as a tool to resolve individual entitlement disputes, it is not only a reliable instrument to localise them in digital markets, but it also has the capacity to solve them. Thanks to its sensitivity to the functioning of markets and to the distribution of economic power, competition law excels in identifying what firms try to capture and to exploit in digital markets. Competition law can take into account the importance of direct and indirect network externalities and firms' cross-leveraging between different assets and product markets; these elements are out of the scope of traditional property law, and regulatory approaches may be too static to take into account the case-by-case individual distribution of economic power. Competition law is a flexible tool to conceptualise network externalities in a legal framework.

This paper found three digital assets to be at the core of the entitlement conflicts: Software platforms, raw data and digital content. The nature of these assets is particular when compared to traditional objects protected by IP or other property rules. The three digital assets are rivalrous. Generally, digital goods are considered to be non-rivalrous: A piece of software or a data set do not depreciate when they are read, copied or executed. But when we take into account the market context, these digital assets do depreciate in their value for the single firm if many others can capture and use them. This is so because value extraction in the digital economy is not infinite. If there is more than one incumbent exercising property entitlements over the same digital asset, then the value extraction can only happen in a rivalrous mode.

The second insight is that the intervention of competition law in digital markets is not unilateral. It shapes strong and precarious regimes of appropriation. In the first entitlement problem, competition intervention weakened Google's ownership position over a software platform. In the second entitlement problem, Facebook's ability to capture value from further network externalities from its own services was also weakened. But in the third entitlement problem, an unfortunate ownership position was created sui generis by the legislator; now it has been reinforced by the intervention of the Autorite de la concurrence. We see, competition law shapes ownership regimes in two ways. It does not always weaken them.

Third, all three entitlement disputes are constructed as conflicts between a dominant firm reigning over a platform, and a less dominant player (Google vs. hardware manufacturers, Facebook-Whatsapp vs. its users, Google vs. press publishers). That is a specificity of the enforcement of competition law in the context of the use of art. 102 TFEU. However, digital markets see not only entitlement conflicts arising between parties of unequal bargaining power.

\footnotetext{
11 "13. You grant us and our affiliates a non-exclusive, transferable, sub-licensable, royalty-free, worldwide license to use any data, content, and other information made available by you or on your behalf in connection with your use of our Platform. This license survives even if you stop using the platform feature. [...]" (Instagram, 2020).
} 
Fourth, and most importantly, competition law does not intervene for the sake of managing entitlement conflicts regarding certain digital assets, but because of the competitive harm that can arise from their appropriation in the context of strong network externalities. The appropriation of software platforms, of raw data and of digital content are relevant for competition policy because they can stand as proxies for the capture or consolidation of network externalities. That can lead to advantages in terms of economic efficiency, but it can also entrench market positions, facilitate exclusionary or exploitative conduct and can therefore harm consumers.

\section{The way forward: What competition law can learn from property rights economics}

Recent government reports tackle the negative externalities of digital firms' conduct either from a competition law view or from a regulatory law view. ${ }^{12}$ To that, this article aims to add the perspective that problems of digital competition, but also problems of digital regulation, can often be interpreted as problems of appropriation.

Network externalities are the engine of value creation in the digital economy. Digital firms strive to exploit software platforms, raw data and digital content in the prospect of benefitting from untapped network externalities. This run for appropriation can be very fruitful in terms of innovation and widespread availability of new products, but once markets have tipped, the dominant firms must be controlled tightly in order to avoid monopoly rent seeking (Petit, 2020). That means, simply because a firm controls competitively superior assets, we should not try to take them away from it; but at the same time, the mere fact that a firm was able to gain control over a superior asset should not suffice to justify an automatic conferral of the most complete property entitlements to it.

We have seen that competition law shapes the exercise of property entitlements in digital markets by configuring the conditions for access and exploitation of different digital assets. The particularity of these assets is that they stand as proxies for network externalities that firms try to capture.

Competition law is a quest for the optimal allocation of entitlements, just as property law is one, or tort law The definite response to the question of what should be regarded as an optimal allocation of entitlements remains a policy choice. According to Melamed and Calabresi, any entitlement dispute can be solved either in order to increase efficiency or in order to make a desired distributive outcome happening. The desired distributive outcome can tend to more equality, but also to more inequality (Melamed \& Calabresi, 1972). That is why the framing of the entitlement disputes is so important. It makes a difference whether we consider a digital dispute purely in terms of competition (with its inclination towards efficiency) or in terms of regulation (which brings in various distributive concerns). Thinking of the disputes as problems of appropriation provides us with a third perspective that can incorporate objectives from both sides. The appropriation perspective can boost competition and regulation with the insights from property rights law and economics.

From property rights economics, we know that markets can be crippled when unnecessary property entitlements are introduced or granted for too long, ${ }^{13}$ as well as when necessary property entitlements are not introduced. ${ }^{14}$ Also, granting property entitlements can have no effect at all. ${ }^{15}$

\footnotetext{
12 Policy makers worldwide are concerned about competitive harm and other negative externalities in digital markets (Akman, 2019; Australian Competition \& Consumer Commission, 2019; Autoridade da concorrência, 2019; Autorité de la concurrence \& Bundeskartellamt, 2016; 2020a; BRICS Competition Law and Policy Centre, 2019; Bundeskartellamt, 2016; Bundesministerium für Wirtschaft und Energie, 2019; Comisión Federal de Competencia Económica, 2018; Competition Bureau Canada, 2018; Crémer et al., 2019; Furman et al., 2019; Japan Fair Trade Commission, 2017; OECD, 2018; Zingales et al., 2019).

${ }^{13}$ Hovenkamp takes the example of "evergreen" extensions of the exclusivity period of patents for certain drugs, which can lead to significant consumer harm (Hovenkamp, 2013, p. 60).

14 The classic tragedy of the commons (Epstein, 2009, p. 11).

${ }^{15}$ See the example of Google vs. press publishers where an ineffective property right has been introduced by the EU legislator.
} 
The novelty of digital markets is that property entitlements over one digital asset have almost always an influence over the value extraction of other assets within the ecosystem of the digital firm. Therefore, competition deciders are advised to take into account the long-term implications of their choices. In digital markets, their decisions are not merely technical, not merely ex post, but ex ante, that will shape future markets, that will define how digital technology is used, and how its immense value is shared throughout society.

\section{Acknowledgments}

The research has received financial support from the French Ministry of Higher Education and Research.

\section{References}

Akman, P. (2019). White paper for the World Economic Forum: Competition Policy in a Globalized, Digitalized Economy. World Economic Forum.

Australian Competition \& Consumer Commission. (2019). Digital platforms inquiry, Final report.

Autoridade da concorrência. (2019). Digital Ecosystems, Big Data and Algorithms-Issues paper.

Autorité de la concurrence. (2020a). Contribution de l'Autorité de la concurrence au débat sur la politique de concurrence et les enjeux numériques.

$\begin{array}{lllllll}\text { Décision } & \mathrm{n}^{\circ} & \text { 20-MC-01 } & \mathrm{du} & 9 & \text { avril } & \text { 2020, }\end{array}$ https://www.autoritedelaconcurrence.fr/sites/default/files/integral_texts/2020-04/20mc01.pdf

Autorité de la concurrence. (2020b, April 9). Press release, Neighbouring rights: The Autorité has granted requests for urgent interim measures presented by press publishers and the news agency AFP (Agence France Presse). https://www.autoritedelaconcurrence.fr/en/press-release/neighbouring-rightsautorite-has-granted-requests-urgent-interim-measures-presented

Autorité de la concurrence \& Bundeskartellamt. (2016). Competition law and Data.

BRICS Competition Law and Policy Centre. (2019). Digital Era Competition: A BRICS View.

Bundesgerichtshof. Beschluss des Kartellsenats vom 23.6.2020—KVR 69/19, (June 23, 2020).

Bundeskartellamt. (2016). Working paper no. B6-113/15-Market Power of Platforms and Networks.

Fallbericht vom 15 Februar 2019, B6-22-16. Facebook; Konditionenmissbrauch gemäß § 19 Abs. 1 GWB wegen unangemessener Datenverarbeitung, (2019).

Bundeskartellamt. (2019, February 7). Press release: Bundeskartellamt prohibits Facebook from combining user data from different sources. https://www.bundeskartellamt.de/SharedDocs/Publikation/EN/Pressemitteilungen/2019/07_02_2019_ Facebook.pdf?_blob=publicationFile \&v=2

Bundesministerium für Wirtschaft und Energie. (2019). A new competition framework for the digital economy. Report by the Commission 'Competition Law 4.0.'

Comisión Federal de Competencia Económica. (2018). Rethinking competition in the Digital Economy.

Competition Bureau Canada. (2018). Big data and innovation: Key themes for competition policy in Canada.

Crémer, J., Montjoye, Y.-A. de, Schweitzer, H., European Commission, \& Directorate-General for Competition. (2019). Competition policy for the digital era. European Commission.

Demsetz, H. (1967). Toward a Theory of Property Rights. The American Economic Review, 57(2), 347359. 
Epstein, R. A. (2009). Property Rights, State of Nature Theory, and Environmental Protection. New York University Journal of Law and Liberty, 4, 1-35.

Case M.7217 - Facebook/ WhatsApp. Commission decision pursuant to Article 6(1)(b) of Council Regulation No 139/2004, (2014).

Case No. M.8228 - Facebook / Whatsapp. Commission Decision of 17.5.2017 imposing fines under Article 14(1) of Council Regulation (EC) No. 139/2004 for the supply by an undertaking of incorrect or misleading information, (2017).

Commission Decision of 27.6.2017 relating to proceedings under Article 102 of the Treaty on the Functioning of the European Union and Article 54 of the Agreement on the European Economic Area (AT.39740-Google Search (Shopping)), (2017).

Commission Decision of 18.7.2018 relating to a proceeding under Article 102 of the Treaty on the Functioning of the European Union (the Treaty) and Article 54 of the EEA Agreement (AT.40099 Google Android), (2018).

European Commission. (2019a, March 20). Press release: Commission fines Google $€ 1.49$ billion for abusive practices in online advertising. https://ec.europa.eu/commission/presscorner/detail/en/IP_19_1770

European Commission. (2019b, July 17). Press release: Commission opens investigation into possible anti-competitive conduct https://ec.europa.eu/commission/presscorner/detail/en/IP_19_4291

of Amazon.

Proposal for a Regulation of the European Parliament and of the Council on contestable and fair markets in the digital sector (Digital Markets Act), $\operatorname{COM}(2020) 842$ final (2020).

Directive (EU) 2019/790 of the European Parliament and of the Council-Of 17 April 2019-On copyright and related rights in the Digital Single Market and amending Directives 96/9/EC and 2001/29/EC, (2019) (testimony of European Parliament and Council).

Furman, J., Coyle, D., Fletcher, A., McAuley, D., \& Marsden, P. (2019). Unlocking digital competition. Report of the Digital Competition Expert Panel. HM Treasury.

Gil, E. (2018). High Growth Handbook (Second edition). http://growth.eladgil.com

Hagiu, A. (2014). Strategic Decisions for Multisided Platforms. MIT Sloan Management Review, Special Collection "Top 10 Lessons on Strategy."

Hovenkamp, H. J. (2013). Consumer Welfare in Competition and Intellectual Property Law. SSRN Electronic Journal. http://www.ssrn.com/abstract=2329150

Instagram. (2020). Instagram Terms of use, Section D, “Things you should know." https://www.instagram.com/about/legal/terms/api/

Japan Fair Trade Commission. (2017). Report of Study Group on Data and Competition Policy.

Matsakis, L. (2020). Buying Giphy Gives Facebook a New Window Into Its Rivals. https://www.wired.com/story/buying-giphy-gives-facebook-new-window/

Mattioli, D. (2020, April 24). Amazon Scooped Up Data From Its Own Sellers to Launch Competing Products. The Wall Street Journal Online. https://www.wsj.com/articles/amazon-scooped-up-datafrom-its-own-sellers-to-launch-competing-products-11587650015?mod=hp_lead_pos2

Melamed, D., \& Calabresi, G. (1972). Property Rules, Liability Rules, And Inalienability: One View of the Cathedral. Harvard Law Review, 85(6), 1089-1128.

Naidoo, V. (2017, April 6). Who Owns the Copyright in an Instagram Image? https://legalvision.com.au/who-owns-the-copyright-in-an-instagram-image/

Beschluss VI-Kart 1/19 (V), Facebook v Bundeskartellamt, (2019).

OECD. (2018). Rethinking Antitrust Tools for Multi-Sided Platforms (p. 230). 
Perzanowski, A., \& Schultz, J. (2016). The end of ownership: Personal property in the digital economy. The MIT Press.

Petit, N. (2020). Big Tech and the Digital Economy. The Moligopoly Scenario. Oxford University Press.

Petit, N., \& Van Cleynenbreugel, P. (2020). General Report Topic 3: EU competition law and the digital economy. In EU Competition Law and the Digital Economy. Protecting Free and Fair Competition in an Age of Technological (R)evolution. The XXIX Congress in The Hague, 2020, Congress Publications Vol. 3. Eleven International Publishing.

Russel, J., \& Lundgren, I. (2016, April 3). Source: Microsoft mulled an \$8 billion bid for Slack, will focus on Skype instead. https://techcrunch.com/2016/03/04/source-microsoft-mulled-an-8-billion-bidfor-slack-will-focus-on-skype-instead/

Shah, V. (2020). Facebook Welcomes GIPHY as Part of Instagram Team. https://about.fb.com/news/2020/05/welcome-giphy/

Varian, H. (2017). Use and abuse of network effects. SSRN Electronic Journal. https://ssrn.com/abstract=3215488

Zech, H. (2015). Daten als Wirtschaftsgut - Überlegungen zu einem „Recht des Datenerzeugers“. Computer und Recht. Zeitschrift für die Praxis des Rechts der Informationstechnologien, 3, 137-146.

Zingales, L., Rolnik, G., \& Maria Lancieri, F. (2019). Stigler Committee on Digital Platforms, Final Report. 